\title{
IMAM KAMPUANG SEBAGAI WALI HAKIM; ANALISIS TERHADAP PUTUSAN PENGADILAN AGAMA TALU NOMOR 502/PDT.G/2011/PA TENTANG ITSBAT NIKAH
}

\author{
Abdul Alim Ashidiqy \\ KUA Kec. Pasaman Kab Pasaman Barat, alim8184@gmail.com \\ Edi Rosman \\ PascasarjanaIAIN Bukittinggi, edimalincayo@gmail.com
}

\begin{abstract}
Marriage is a facility that Allah arranges in such a way that human biological needs are channeled and fulfilled respectfully and well. To carry out a marriage, the role of the guardian of marriage is very important because in his hand a marriage becomes legitimate, in addition to fulfilling the other pillars, including witnesses and dowry. If these pillars are not fulfilled and ignored, the marriages that are carried out are not recognized by the syarak. The decision of the Talu Religious Court by ordering a marriage without a legal guardian according to the rules of Islamic law and legislation in Indonesia certainly seems to have ignored the provisions of the figh and the positive law that applies in Indonesia. This is because there are no rules in fiqh and also positive laws that allow a priest to be allowed to marry someone who has no relationship with him. The appointment of the village priest as the guardian of the judge in a marriage is not based on reasons that can be justified by syarak, because in the subsection of the judge's guardian in the constellation of Islamic law and the positive law applicable in Indonesia is the government or the person authorized by the government to be the judge's guardian. In the marriage certificate request that has been granted by the panel of judges, the Religious Religious Court Number: 502 / Pdt.G / 2011 / PA has ignored important aspects in a legal product because of lack of attention to aspects of Islamic law (fiqh) that never provide opportunities to people who are not have a relationship with a woman nasab.
\end{abstract}

Keywords: Imam Kampung, Wali Hakim, Analisis Putusan

\begin{abstract}
Abstrak
Pernikahan merupakan fasilitas yang Allah Swt atur sedemikian rupa agar kebutuban biologis manusia tersalurkan dan terpenubi secara terhormat dan baik. Untuk melangsungkan sebuah pernikahan, maka peran wali nikeah menjadi sangat penting karena di tangannyalah sebuah pernikahan menjadi sah, di samping terpenubinya rukun-rukun yang lainnya, antara lain adanya saksi dan mahar. Apabila rukun-rukun ini tidak terpenubi dan diabaikan maka pernikahan yang dilaksanakan tidak diakui kesabhannya oleh syarak. Keputusan Pengadilan Agama Talu dengan mengitsbatkean pernikahan tanpa wali yang sah menurut aturan bukum Islam dan juga perundang-undangan di Indonesia tentu saja terkesan sudah mengabaikan ketentuan fiqh dan bukum positif yang berlaku di Indonesia. Hal ini karena tidak adanya aturan dalam fiqh dan juga bukum positif yang memungkinkan bolehnya seorang imam kampuang untuk menikabkan seseorang yang tidak punya bubungan nasab dengannya. Pengangkatan imam kampung sebagai wali hakim dalam sebuah perkawinan tidak didasarkan kepada alasan yang dapat dibenarkan oleh syarak, karena secara subsatansi wali hakim dalam konstelasi hukum Islam dan bukum positif yang berlaku di Indonesia adalah pemerintah atau orang yang ditauliyabkan pemerintah untuk menjadi wali hakim. Dalam permohonan isbat nikah yang telah dikabulakan oleh majlis bakim Pengadilan Agama Talu Nomor: 502/Pdt.G/2011/PA telah mengabaikan aspek penting dalam sebuah produk bukum karena kurang memperbatikan aspek. bukum Islam (figh) yang tidak pernah memberi peluang kepada orang yang tidak mempunyai bubungan nasab dengan seorang perempuan.
\end{abstract}

Kata Kunci: Imam Kampung, Wali Hakim, Analisis Putusan 


\section{PENDAHULUAN}

Pensyariatan pernikahan oleh Allah Swt kepada hamba-Nya adalah merupakan salah satu bukti dari kecintaan-Nya. Pernikahan merupakan fasilitas yang Allah Swt atur sedemikian rupa agar kebutuhan biologis manusia tersalurkan dan terpenuhi secara terhormat dan baik. Di dalam wujud kecintaan itu, Allah Swt akan limpahkan berbagai keberkahan dan kebahagiaan hidup yang akan dirasakan melalui ikatan tali pernikahan itu. Karena dengan pernikahan akan menjadikan mahkluk-Nya hidup berpasangan yang akan melengkapi kekurangan antara suami dan isteri, serta akan menumbuhkan butir-butir cinta dan kasih sayang antara sesama pasangannya ${ }^{1}$.Inilah apa yang diisyaratkan oleh Allah Swt dalam QS al-Rum [30]: 21.

Untuk melangsungkan sebuah pernikahan, maka peran wali nikah menjadi sangat penting karena di tangannyalah sebuah pernikahan menjadi sah, di samping terpenuhinya rukun-rukun yang lainnya, antara lain adanya saksi dan mahar. Apabila rukunrukun ini tidak terpenuhi dan diabaikan maka pernikahan yang dilaksanakan tidak diakui kesahhannya oleh syarak. Keberadaan wali nikah ini sangat menjadi perhatian yang besar bagi berbagai kalangan ulama fikih. Di Indonesia pentingnya wali dalam pernikahan difatwakan oleh Majelis Ulama Indonesia tentang sahnya suatu pernikahan, dan salah satunya adalah adanya wali nikah ${ }^{2}$.

Dalam perspektif hukum Islam, wali nikah yang lebih berhak untuk menikahkan seorang wanita adalah wali nasab, yakni lakilaki yang terdiri dari keluarga calon mempelai

${ }^{1}$ Sayyid Sabiq, Fiqh al-Sunnah, (Beirut: Dar al-Fikr, 2008), Juz II, h. 456

${ }^{2}$ Direktorat Jenderal Bimbingan Masyarakat Islam dan Penyelenggaraan Haji Departemen Agama RI, Himpunan Fatwa MajelisUlama Indonesia, (Jakarta: [t.tp], 2003), h. 163 wanita dan berhak menjadi wali ${ }^{3}$. Apabila wali nasab tidak ada, maka hakim yang berada pada daerah itu yang menjadi wali nikahnya.Dasar hukum wali hakim adalah merujuk kepada hadis yang berasal dari 'Aisyah yang diriwayatkan oleh imam yang empat kecuali alNasa'i yaitu:

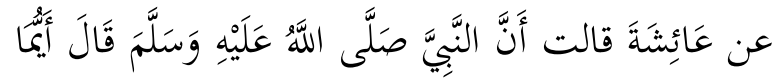

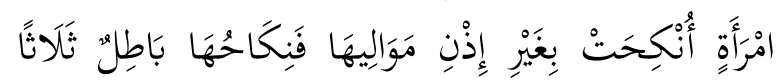

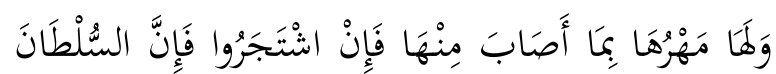

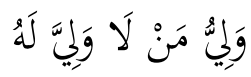

"Dari 'Aiyah ia berkata, bahwa Nabi Mubammad Saw bersabda,wanita manapun yang menikah tanpa izin walinya maka nikabnya batil (diucapkan tiga kali), dan wanita itu tetap memperoleh maharnya disebabkan apa yang telab menimpa kepadanya, jika mereka enggan maka sultan (penguasa) menjadi wali nikah bagi yang tidak memiliki wali."

Berdasarkan hadis di atas maka dapat disimpulkan bahwa yang dimaksud wali hakim adalah penguasa resmi yang dapat bertindak sebagai wali nikah (wali hakim) ketika wanita yang hendak menikah tidak memiliki wali nasab, atau ada sebab lain yang mengaharuskan berpindah dari wali nasab kepada wali hakim. Agar pelaksanaan pernikahan itu tidak memiliki kendala maka penguasa dapat menunjuk pejabat tertentu yang dianggapnya mampu dan cakap dalam menjalankan tugasnya.

Pemerintah Indonesia juga mengatur dan menetapkan tentang wali nikah yang harus dipenuhi dalam pernikahan dalam Kompilasi Hukum Islam (KHI) pasal 19 yang menyebutkan bahwa wali nikah dalam perkawinan merupakan rukun yang harus dipenuhi bagi calon mempelai wanita yang

${ }^{3} \mathrm{M}$. Yunus, Hukum Perkawinan dalam Islam menurut Empat Mąhab, (Jakarta: PT. Hidakarya Agung, 1996), h. 55.

${ }^{4}$ Muhammad ibn Ismail, Subul al-Salam, (Semarang: Toha Putra), Juz III, h. 117-118. 
bertindak untuk menikahkannya. Sejalan dengan KHI di atas, hukum positif yang mengatur tentang wali hakim juga termaktub dalam KMA No. 30 tahun 2005 tentang Wali Hakim. Ketentuan tentang wali nikah juga ditegaskan kembali dalam Peraturan Menteri Agama No. 11 tahun 2007 tentang Pencatatan Nikah. Pada pasal 18 disebutkan bahwa wali nikah termasuk salah satu bagian yang urgensi di dalam pelaksanaan pernikahan. Tanpa adanya wali nikah maka nikah tidak sah dan tidak mempunyai kekuatan hukum secara agama dan perundang-undangan.

Dalam Kompilasi Hukum Islam (KHI) pasal 20 telah ditetapkan bahwa wali nikah terkategori kepada wali nasab dan wali hakim. Wali hakim akan bertindak menjadi wali nikah apabila wali nasab tidak ada atau tidak mungkin menghadirkannya atau tidak diketahui tempat tinggalnya atau gaib atau adhal atau enggan, (pasal 23 ayat 1). Ketentuan yang ada dalam KHI pasal 20 tersebut mengisyaratkan bahwa wali yang di luar dari ketentuan ini tidak termasuk kepada kategori wali nikah. Kodifikasi semacam ini memberikan suatu kepastian dan ketegasan hukum dalam menetapkan wali nikah untuk menutup peluang adanya wali-wali lain yang bertindak sebagai wali.

Dalam kenyataannya, tidak semua perkawinan yang mengikuti ketentuan tersebut. Hal ini salah satunya terjadi di jorong Padang Tujuh Nagari Aua Kuniang Kec. Pasaman Kab. Pasaman Barat, di mana kedua pasangan itu tidak dinikahkan oleh wali nasab dan wali hakim, tetapi dinikahkan oleh wali kampuang yang sehari-hari bertindak sebagai imam dalam suatu kaum (suku) dalam susunan masyarakat adat di sana. Perkawinan itu dilaksanakan pada tanggal 25 Juli 2011 di Jambu Baru, Jorong Padang Tujuh
Kenagarian Aua Kuniang Kec. Pasaman Kab. Pasaman Barat. ${ }^{5}$

Untuk mendapatkan pengakuan resmi dari negara, maka 5 bulan setelah menikah, pasangan suami istri tersebut mengajukan permohonan kepada Pengadilan Agama Talu untuk diisbatkah pernikahannya ${ }^{6}$. Berdasarkan permohonan suami istri tersebut, Pengadilan Agam Talu mengabulkan permohonan mereka dan mengistbatkan pernikahan tersebut serta memerintahkan untuk didaftarkan ke Kantor Urusan Agama Kecamatan untuk dikeluarkan buku nikahnya.

Keputusan Pengadilan Agama Talu dengan mengitsbatkan pernikahan tanpa wali yang sah menurut aturan hukum Islam dan juga perundang-undangan di Indonesia tentu saja terkesan sudah mengabaikan ketentuan fiqh dan hukum positif yang berlaku di Indonesia. Hal ini karena tidak adanya aturan dalam fiqh dan juga hukum positif yang memungkinkan bolehnya seorang imam kampuang untuk menikahkan seseorang yang tidak punya hubungan nasab dengannya. Putusan Pengadilan Agama Talu dikhawatirkan akan berdampak kepada ketidaktaatan masyarakat untuk mengikuti aturan perundang-udangan yang berlaku di Indonesia dan bisa jadi membuka peluang untuk terjadinya nikah tanpa wali. Oleh karena itu persoalan ini perlu dibahas lebih lanjut dengan mempertanyakan alasan-alasan yang melatarbelakangi lahirnya keputusan tersebut dan apakah alasan-alasan itu dapat diterima oleh ketentuan hukum Islam.

5Penetapan Putusan Pengadilan Talu Nomor: 502/Pdt.G/2011/PA. Talu tentang Isbat Nikah.

${ }^{6}$ Dalam pasal 7 ayat 2 KHI dinyatakan bahwa "Dalam hal perkawinan tidak dapat dibuktikan dengan Akta Nikah, dapat mengajukan isbat nikahnya ke Pengadilan Agama". Direktorat Jenderal Pembinaan Kelembagaan Agama Islam, Kompilasi Hukum Islam, ([t.tp]:[t.p], 2000), h. 15 


\section{WALI NIKAH DALAM FIQH DAN HUKUM POSITIF DI INDONESIA}

Pembahasan tentang perwalian dalam Islam memiliki ruang lingkup yang cukup luas. Sehingga ulama mengklasifikasi wali ke dalam dua kategori yaitu: perwalian umum dan khusus. Perwalian khusus adalah perwalian terhadap jiwa dan harta seseorang. Maka untuk pembahasan perwalian dalam pernikahan maka ini temasuk ke dalam kategori perwalian terhadap jiwa seseorang. ${ }^{7}$

Secara etimologi kata wali terambil dari bahasa Arab, dengan akar kata waliya-yaliyuwalyan yang berarti amat dekat kepada, mengikutinya, mengiringinya tanpa batas. Istilah ini juga ada dalam bentuk kata al-waalii yang artinya hakim, pemerintah, dan wali. ${ }^{8}$

Dalam referensi lain dijelaskan bahwa secara bahasa wali memiliki arti al-nusbrah atinya pertolongan, dan berdirinya seseorang karena perintah orang lain.' Kemudian wali juga dapat berarti al-mahabbah, yaitu kasih sayang, al-sulthah yang berarti kekuasaan,dan alqudrah yang berarti kemampuan, sehingga muncul kata al-waali atau orang yang mempunyai kekuasaan atau kemampuan. ${ }^{10}$

Sedangkan secara terminologi, para ulama telah mengemukakan pendapatnya tentang definisi wali ini. Badran Abu al-'Anain Badran menjelaskan bahwa perwalian mempunyai arti kemampuan untuk memunculkan atau melaksanakan akad dan kegiatan lainnya yang berlangsung tanpa berhenti atas permintaan seseorang. ${ }^{11}$ Kemudian Muhammad Jawad Mughniyah memberikan pengertian perwalian dengan

${ }^{7}$ SayyidSabiq, Fiqhal-Sunnah, JilidII, (Beirut:DaralFikr,2008), h.511. Lihat juga Wahbah al-Zuhayli, Fiqh al-Islam wa Adillatuh, (Damaskus: Dar al-Fikr, 1989), Cet ke-2, Juz VII, h. 746

${ }^{8}$ Mahmud Yunus, Kamus Arab-Indonesia, Jakarta: Yayasan Penyelenggara Penterjemah dan Pentafsir Alquran,1973), h.5-6.

${ }^{9}$ Badran Abu al- 'Ainain Badran, al-Fiqh al-Muqaran li al-Abwal al-Syakhsiyyah, (Beirut Lubnan: Dar alNahdah al 'Arabiyyah, [t.th]), Juz I, h. 15-16

${ }^{10}$ Wahbah al Zuhayli, al-Figh..., h. 186

${ }^{11}$ Badran Abu al 'Anain Badran, al-Fiqh..., h. 15-16 makna suatu kekuasaan atau wewenang syar'i atas segolongan manusia, yang dilimpahkan kepada orang yang sempurna, karena kekurangan tertentu pada orang yang dikuasai itu, demi kemaslahatannya sendiri. ${ }^{12}$

Wahbah al-Zuhayli mengungkapkan bahwa para fuqaha mendefinisikan wali dengan kekuasaan/otoritas yang dimiliki seseorang untuk secara langsung melakukan suatu tindakan tanpa harus bergantung (terikat) atas seizin orang lain. ${ }^{13}$ Sedangkan Amir Syarifudin memformulasikan bahwa wali dalam pernikahan adalah seorang yang bertindak atas nama mempelai perempuan dalam suatu akad nikah. ${ }^{14}$

Apabila dihubungkan dengan pernikahan, maka berdasarkan beberapa definisi-definisi di atas dapat disimpulkan bahwa wali dalam pernikahan adalah seorang yang mempunyai hak dan kewenangan untuk menikahkan seorang wanita yang berada di bawah kewenangannya untuk menikah dengan seorang pria karena ketidak-mampuannya menjadi wali bagi dirinya sendiri atau karena ketidakberwenangannya untuk melakukan hal tersebut.

Pentingnya wali dalam sebuah pernikahan didasarkan kepada kepada beberapa dalil ayat al-Qur`an dan Hadis-hadis Nabi SAW. Di antaranya terdapat dalam QS Surat al-Baqarah [2]: 232:

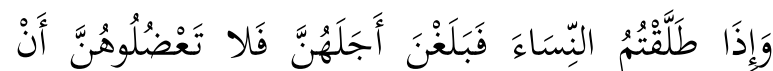

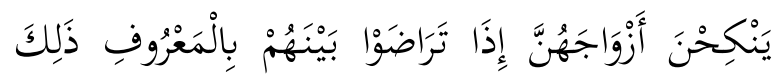

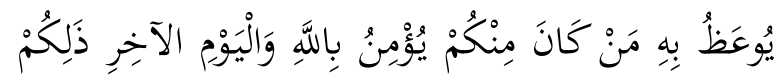

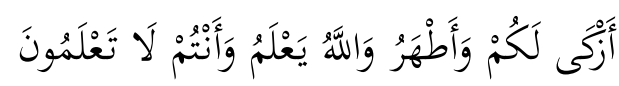
"Apabila kamu menalak istri-istrimu, lalu babis iddahnya, maka janganlah kamu (para wali) menghalangi mereka kawin lagi dengan bakal

12 Muhammad Jawad Mughniyah, Fiqh Lima Madz̧hab: Ja'fari, Hanafi, Maliki, Syafi'i, Hambali, Terj., (Jakarta: Penerbit Lentera, 2006), h. 176

${ }^{13}$ Wahbah al Zuhayli, al-Fiqh..., h.186

${ }^{14}$ Amir Syarifuddin, Hukum Perkawinan di Indonesia, (Jakarta: Kencana, 2006), h.96 
suaminya, apabila telah terdapat kerelaan di antara mereka dengan cara yang makruf. Itulah yang dinasehatkan kepada orang-orang yang beriman di antara kamu kepada Allah dan hari kemudian. Itu lebih baik bagimu dan lebih suci. Allah mengetahui, sedang kamu tidak mengetahui”.

Ibnu Katsir di dalam tafsirnya menjelaskan bahwa sebab turunnya pasal di atas berkenaan dengan seorang sahabat yang bernama Ma'qal ibn Yasar yang enggan untuk menikahkan saudarinya dengan mantan suami setelah habis masa 'Iddah. Sehubungan dengan sikapnya itu maka Allah menurunkan firmanNya sebagai teguran kepada Ma'qal ibn Yasar. Ulama menjelaskan bahwa ayat di atas secara zahir memberikan pemahaman tentang seorang wanita tidak mempunyai hak untuk menikahkan dirinya. ${ }^{15}$ Muhammad 'Ali al-Sayis dalam kitabnya Tafsir Ayat al-Abkam menerangkan bahwa ayat ini sebagai dasar pembenaran pendapat yang menyatakan bahwa tidak sah nikah tanpa wali. ${ }^{16}$

Selain itu, dalam QS al-Baqarah [2]: 221, Allah SW'T befirman:

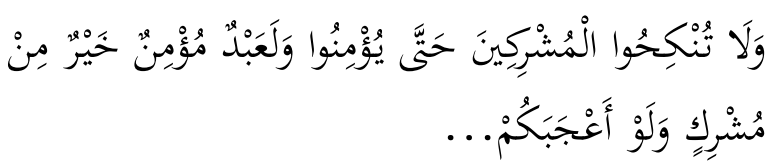

"Dan janganlah kamu menikabkan orang-orang musyrik (dengan wanita-wanita mukmin) sebelum mereka beriman. Sesunggubnya budak yang mukmin lebib baik dari orang musyrik walaupun dia menarik batimu."

Sama halnya dengan surat al-Baqarah ayat 232 di atas, bahwa sasaran pada firman Allah Swt ayat 221 ini kepada para wali. Sehingga ulama memahami bahwa mesti adanya wali dalam suatu pernikahan. ${ }^{17}$

${ }^{15} \mathrm{Abu}$ al-Fida' Ismail ibn Umar ibn Katisr alQarasyi al-Bashari, Tafsir al-Qur'an al-'Az̧im, ([t.tp]: Dar al-Thayyibah, 1999), Juz. I, h. 631

${ }^{16}$ Muhammad Ali al-Sayis, Tafsir Ayat al-Abkam, ([t.tp]: [t.terbit], 2002), Juz ke-I, h. 161

${ }^{17}$ Ibn Rusyd al-Hafidi, Bidayah al-Mujtabid wa Nihayah al-Muqtashid, (Kairo: Dar al-Hadits, 2004), Juz III, h. 37.
Selain ayat al-Qur`an, Nabi SAW juga menegaskan pentingnya wali nikah ini sebagai sebuah kemestian dalam pernikahan. Hadishadis itu antara lain diriwayatkan oleh Abu Dawud dari Abu Musa al-Asy'ari:

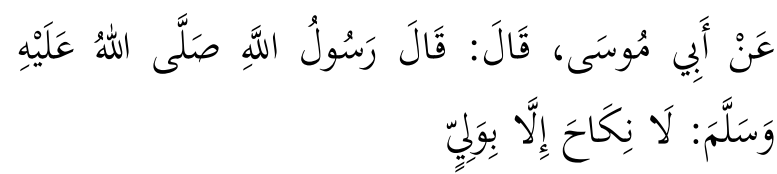

"Dari Abi Musa beliau berkata, Rasulullah Saw bersabda: Tidak sab nikah tanpa ada wali"18

Semakna dengan redaksi hadis di atas, Rasulullah SAW juga bersabda:

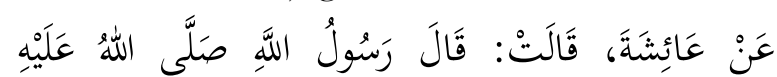

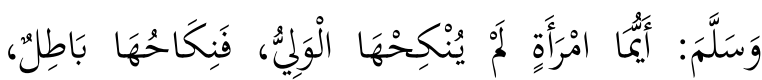

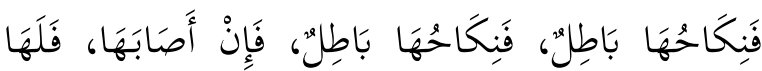

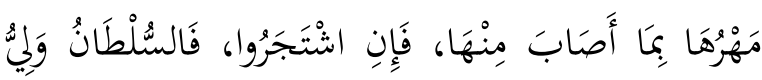

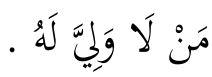

"Dari Aisyah berkata; Bersabda Rasulullah Saw: Siapa sajawanita yang dinikabkan dengan tanpa seizin walinya, maka nikahnya batal (belian mengulanginya tiga kali).Jika lelakinya telah menyetububinya, maka ia berhak atas mabarnya, karena ia telah menghalalkan kehormatannya. Jika pibak wali enggan menikabkan, maka hakimlah yang bertindak menjadi wali bagi seseorang yang tidak ada walinya." 19

Hadis di atas menegaskan bahwa ketika seorang wanita menikah tanpa ada wali, maka nikahnya batal. Pembatalan itu ditegaskan (ta'kid) sebanyak tiga kali. Batal nikah karena tidak ada wali berarti tidak sah sebuah pernikahan. Dengan demikian ini mengisyaratkan bahwa keabsahan sebuah pernikahan tergantung juga dengan wali. Namun hal ini juga bukan berarti seorang wali bebas berkehendak menolak perwalian anak ketika anaknya mau menikah dan sudah ada pasangan yang sekufu. Karena seandainya wali

\footnotetext{
${ }^{18} \mathrm{Abu}$ Dawud Sulaiman ibn al-Asy'ats al-Sijistani, Sunan Abi Dawud, (Surabaya:Maktabah Dahlan, [t.th]), Jilid 2, h229

${ }^{19}$ Ibid, h.229
} 
enggan ('adhal) untuk menikahkannya, maka hakim dapat bertindak menjadi walinya.

Pentingnya wali dalam pernikahan juga dituliskan oleh Imam al-Syafi'i dalam kitab alUmm. Diriwayatkan bahwa sahabat menegakkan aturan tentang pentingnya wali dalam menikahkan seorang wanita. Seperti kisah Ikrimah bin Khalid, yang pernah mengalami suatu peristiwa di mana dalam perjalanan yang ditempuhnya ia melihat seorang wanita yang sudah janda yang menyerahkan urusan pernikahannya kepada seorang laki-laki yang bukan walinya secara nasab. Ketika hal itu didengar oleh Umar ibn Khatab, maka Umar menjatuhkan hukuman dera kepada orang yang menikah itu dan juga kepada orang yang menikahkannya, sekaligus membatalkan pernikahannya. ${ }^{20}$

Merujuk kepada riwayat di atas, bahwa pria yang bertindak sebagai wali nikah itu kompetensinya tidak diakui sebab secara hukum pria tersebut tidak masuk dalam kualifikasi syar'i sebagai wali nikah. Sehingga dengan ijtihadnya Umar menjatuhkan dera. Vonis hukum berupa dera secara substansi hukum mengisyaratkan adanya muatan pelanggaran hukum yang sangat prinsipil untuk menjaga kepentingan umum. Bahkan ketika pelanggaran dilakukan akan berdampak kepada pengrusakan lebih banyak seperti merusak tatanan hukum, sosial serta memunculkan mudarat.

Kemudian selain dari penjatuhan hukum dera ternyata Umar ibn Khattab memutuskan dengan perintahnya untuk mengulang kembali pernikahan pasangan tersebut setelah membatalkan pernikahan sebelumnya. Pembatalan nikah berarti mengandung makna bahwa pernikahan itu belum memenuhi rukun dan syarat. Kemudian dengan menganalisa kasus di atas bahwa ketika seorang yang tidak berhak menjadi wali nikah dapat diberi sanksi dan dapat membatalkan pernikahan, tentu lebih fatal lagi akibatnya ketika menikah tanpa mengahadirkan seorang wali. Justeru akan membuat pernikahan juga batal dan tidak sah.

Di Indonesia persoalan wali nikah juga termasuk hal sangat kruisal dalam melangsungkan pernikahan bagi seorang wanita muslim. Hal ini dapat dilihat dalam Kompilasi Hukum Islam pada pasal pasal 19 dinyatakan bahwa wali nikah dalam perkawinan merupakan rukun yang harus dipenuhi bagi calon mempelai wanita yang bertindak untuk menikahkannya. Sejalan dengan itu, Menteri Agama juga mengeluarkan Peraturan Menteri Agama No. 11 tahun 2007 tentang Pencatatan Nikah. Dalam pasal 18 ditegaskan bahwa wali nikah termasuk salah satu bahagian yang urgensi di dalam pelaksanaan pernikahan. Tanpa adanya wali nikah maka nikah tidak sah dan tidak mempunyai kekuatan hukum secara agama dan perundang-undangan.

Mencermati dari pasal-pasal peraturan di atas jelas terlihat bahwa pemerintah mencoba untuk mengakomodir semua dalildalil agama Islam tentang wali nikah melalui para ulama dan praktisi hukum di Indonesia. Sehingga terbentuklah formula kodifikasi hukum serta aturan-aturan yang mengatur tentang wali nikah.

\section{PEMBAGIAN DAN URUTAN WALI NIKAH}

Pembahasan tentang pembagian dan urutan wali nikah tentu tidak terlepas dari berbagai pandangan para ulama. ${ }^{21}$ Perwalian dalam permasalahan nikah bagi kalangan Hanafiyah termasuk kepada al-Wilayah al-Nafs. Hanafiyah mengemukakan pembagian wali yang intinya merupakan wali yang ada hubungan nasab dengan seorang perempuan dan wali hakim. Walaupun istilah wali ijbar juga dikenal di kalangan mereka, tetapi yang

${ }^{20}$ Imam Muhammad ibn Idris al-Syafi'i, al-Umm, ([t.tp]: Dar al-Wafa', 2001), Juz VI, h. 34

${ }^{21}$ Ibid.h. 187-208 
dimaksud dengan wali mujbir adalah semua yang berwenang menjadi wali dan mereka hanya mempunyai otoritas penuh untuk menikahkan perempuan-perempuan yang dungu, masih kecil, kurang waras, dan budak perempuan. Walaupun berbeda dalam menempatkan urutan-urutan wali, tetapi pada intinya tetap mensyaratkan adanya hubungan nasab, dan jika tidak ada, maka yang berhak menjadi wali adalah wali hakim.

Ulama Malikiyah menetapkan bahwa pernikahan pada prinsipnya mesti dinikahkan oleh wali nikah. Mereka membagi wali kepada dua kategori, yaitu wali mujbir dan wali ghairu mujbir. Ijbarnya seorang wali kepada wanita hanya disebabkan dua hal yakni; wanita gadis dan wanita kecil. Status wali mujbir ini juga diperuntukkan kepada tuan yang memiliki budak, ayah, dan orang yang menerima wasiat dari ayah ketika ayah meninggal. Sedangkan wali ghairu mujbir adalah wali yang dapat menikahkan seorang wanita baligh ketika telah mendapatkan persetujuan wanita itu, yaitu anak laki-laki sampai ke bawah, saudara lakilaki, kakek, paman (saudara laki-laki ayah), anak paman, orang yang memerdekakan budak wanita, al-kafil (penjamin; kafalab), dan jika semua itu tidak ada atau tidak memungkinkan, maka wali hakimlah yang bertindak sebagai wali.

Bagi ulama Syafi'iyah wali nikah bagi seorang wanita yang hendak menikah adalah ketentuan syarat yang mutlak terhadap sahnya aqad. Seorang wanita tidak diperkenankan menikahkan dirinya sendiri dan menikahkan wanita lain. Konsep perwalian bagi mereka juga terbagi kepada dua macam, yaitu wali mujbir dan wali gharu mujbir (wali mukhtar). Wali mujbir adalah wali yang mempunyai kewenangan menikahkan wanita gadis tanpa butuh izinnya, baik itu gadis kecil ataupun gadis dewasa. Namun dianjurkan untuk meminta izin wanita dewasa dengan cara diamnya ketika ditanya untuk menikah. Wali mujbir yang dimaksud adalah salah ayah dan kakek apabila tidak ada ayah. Pada prinsipnya pendapat ulama Syafi'iyah sama dengan ulama lainnya, yaitu bahwa hak menikahkan hanya ada pada wali nasab dan wali hakim. Sedangkan dalam masalah urutan wali, mereka berbeda dengan ulama Hanafiyah dan Malikiyah.

Menurut ulama Hanabilah, seorang wanita juga tidak diperkenankan menikahkan dirinya sendiri sebagaimana pendapat ulama Maikiyah dan Syafi'iyah. Mereka juga membagi wali kepada wali mujbir dan wali ghairu mujbir. Berbeda dengan ulama lainnya, hak ijbar wali dalam pandangan mereka merupakan hak ayah, orang yang menerima wasiat dari ayah, dan juga wali hakim. Sedangkan wali mukhtar adalah seluruh kerabat nasab yang berpotensi menjadi wali dengan memprioritaskan yang paling dekat hubungan kekerabatannya, seperti ayah harus didahulukan dari kakek dan anak, dan seterusnya. Pada prinsipnya mereka juga membagi wali ini kepada dua macam saja, yaitu wali disebabkan nasab dan wali hakim apabila wali tidak ada atau enggan menikahkan.

Dengan demikian, para ulama mazhab pada dasarnya tidak berbeda dalam menetapkan wali nikah yang harus berasal dari keluarga laki-laki yang mempunyai hubungan nasab dengan perempuan yang akan dinikahkan. Apabila hal itu tidak ada atau tidak mau menikahkan dengan alasan-alasan tertentu, maka wali hakimlah yang menikahkan perempuan tersebut. Dari paparan di atas juga tidak ada gambaran adanya peluang bagi pihakpihak yang tidak mempunyai hubungan nasab dengan seorang perempuan untuk mengakadkan pernikahannya, kecuali diwasiatkan oleh ayah sebelum meninggal dunia. Atau seorang wali nasab yang mewakilkan kepada orang lain haknya tersebut karena sesuatu alasan yang dibenarkan oleh syarak.

Peraturan tentang wali nikah juga diatur dalam hukum positif di Indonesia. Pasal 
20 (2) Kompilasi Hukum Islam menyebutkan bahwa wali nikah terdiri dari wali nasab dan wali hakim. Tentang urutan wali nasab disebutkan dalam pasal $21 \mathrm{KHI}$ yang pada prinsipnya membagi wali nasab kepada empat kelompok yang harus didahulukan sesuai dengan urutan tersebut. Kelompok urutan pertama adalah kelompok kerabat laki-laki garis lurus ke atas, yaitu ayah, kakek dari pihak ayah, dan seterusnya. Kelompok urutan kedua adalah saudara laki-laki kandung atau saudara laki-laki seayah dan keturunan laki-laki mereka. Kelompok yang erada pada urutan ketiga adalah kerabat paman, yakni saudara laki-laki kandung ayah, dan keturunan laki-laki mereka. Terakhir kelompok urutan keempat adalah saudara laki-laki kandung kakek, saudara lakilaki seayah dan keturunan laki-laki mereka.

Sehubungan dengan wali hakim, maka terdapat hadis-hadis Rasulullah SAW yang menjadi pedoman untuk itu, antara lain hadis yang berasal dari 'Aisyah yang diriwayatkan oleh imam yang empat kecuali al-Nasa'i yang artinya; "... wanita manapun yang menikah tampa iz̨in walinya maka nikahnya batil (diucapkan tiga kali), dan wanita itu tetap memperoleb maharnya disebabkan apa yang telah menimpa kepadanya, jika mereka enggan maka sultan (penguasa) menjadi wali nikah bagi yang tidak memiliki wali." (HR Abu Dawud). ${ }^{22}$

Sayyid Imam Muhammad ibn Ismail menjelaskan bahwa yang dimaksud dengan kata sultan dalam hadis di atas adalah pejabat tertinggi dalam negara. Karena sultan (otoritas) adalah orang yang mempunyai kekuasaan, baik ia zalim maupun adil, karena hadis-hadis yang memerintahkan mentaati sultan bersifat umum yang mencakup sultan yang adil maupun zalim. ${ }^{23}$ Ahmad Husairi berpendapat bahwa yang dimaksud dengan sultan adalah Imam Akbar (Kepala Negara) atau hakim atau siapa saja yang dilimpahkan wewenang oleh

\footnotetext{
${ }^{22}$ Abu Dawud Sulaiman, Sunan...,. h229

23 Muhammad ibn Ismail al-Kahlani, Subul..., h.
}

keduanya menjadi wali di saat tidak ada wali nasab. Sultan adalah wali bagi yang tidak ada walinya, sebagaimana Negus mengawinkan Ummu Habibah dengan Rasulullah SAW ketika Ummu Habibah berada di Habsyah. ${ }^{24}$

Sehubungan dengan pengertian sultan, Wahbah al-Zuhayli juga menjelaskan bahwa yang dimaksud dengan sultan adalah imam, hakim atau orang yang diberikan tugas untuk mengemban kewenangan dalam menikahkan. ${ }^{25}$ Kemudian di dalam literatur lain seperti dalam kitab I'anah al-Thalibin menjelaskan bahwa istilah pemimpin negara disebutkan juga dengan istilah Imam al-A'ŗham (kepala Negara). ${ }^{26}$ Pendapat ini mengisyaratkan bahwa walaupun dasar pemerintahan bukan Islam, namun pimpinan negaranya muslim maka tetap saja kewenangan pemimpin negara yang menjadi wali dalam perkawinan jika terjadi kekosongan wali nasab.

Berdasarkan keterangan di atas maka dapat disimpulkan bahwa dalam perspektif fikih yang dimaksud wali hakim adalah penguasa resmi yang dapat bertindak sebagai wali nikah (wali hakim) ketika wanita yang hendak menikah tidak memiliki wali nasab, atau ada sebab lain yang mengaharuskan berpindah dari wali nasab kepada wali hakim. Agar pelaksanaan pernikahan itu tidak memiliki kendala maka penguasa dapat menunjuk pejabat kepada orang-orang yang dianggapnya mampu dan cakap dalam menjalankan tugasnya.

Dalam tatanan hukum positif di Indonesia, pemerintah telah mengatur sehubungan dengan wali hakim. Di samping Isntruksi Presiden RI Nomor 1 tahun 1991 tentang Kompilasi Hukum Islam, Menteri Agama sebagai pembantu penguasa tertinggi

${ }^{24}$ Ahmad Husairi, al-Nikah wa al-Qadhaya alMuta'aliqah Bibi, (Kairo: Maktabah Kulliatil Azhar, 1968), h. 508

${ }^{25}$ Wahbah al-Zuhayli, al-Fiqh..., h.207

${ }^{26}$ Sayyid al-Bakri ibn al-Sayyid Muhammad Syatha al-Dimyathi al-Mishri, I'anath al-Thalibin, ([ttp]: alHaramain, [t.th]), Juz III, h. 318 
yakni Presiden, juga turut mengatur dalam penentuan wali hakim. Dalam Kompilasi Hukum Islam (KHI) pasal 20 telah ditetapkan bahwa wali hakim ialah wali nikah yang ditunjuk oleh Menteri Agama atau pejabat yang ditunjuk olehnya yang diberi hak dan kewenangan untuk bertindak sebagai wali nikah, (Pasal 1 poin b).

Dalam Peraturan Menteri Agama Nomor 30 tahun 2005 pasal 1 ayat 2 dinyatakan bahwa yang dimaksud dengan wali hakim adalah Kepala Kantor Urusan Agama Kecamatan yang ditunjuk oleh Menteri Agama untuk bertindak sebagai wali nikah bagi calon mempelai wanita yang tidak mempunyai wali. Menteri Agama di samping menunjuk Kepala KUA Kecamatan, justeru diperkenankan kepada Penghulu dan Pembantu Pegawai Pencatan Nikah (P3N) untuk menjadi wali hakim. Hal ini tertuang dalam PMA No. 30 tahun 2005 pasal 3 sebagai berikut:

1. Kepala Kantor Urusan Agama Kecamatan (KUA) dalam wilayah kecamatan yang bersangkutan ditunjuk menjadi wali hakim untuk menikahkan mempelai wanita sebagaimana dimaksud dalam pasal 2 pasal (1) Peraturan ini.

2. Apabila Kepala KUA Kecamatan sebagaimana dimaksud pada pasal (1) berhalangan atau tidak ada, maka Kepala Seksi yang membidangi tugas Urusan Agama Islam atas nama Kepala Kantor Departemen Agama kabupaten/kota diberi kuasa untuk atas nama Menteri Agama menunjuk salah satu Penghulu pada kecamatan tersebut atau terdekat untuk sementara menjadi wali hakim dalam wilayahnya.

3. Bagi daerah terpencil atau sulit dijangkau oleh transportasi, maka Kepala Seksi yang membidangi tugas Urusan Agama Islam atas nama Kepala Departemen Agama menunjuk pembantu penghulu pada kecamatan tersebut untuk sementara menjadi wali hakim dalam wilayahnya.
Dari beberapa peraturan yang ada tentang wali hakim ini, tidak ada peluang untuk menjadikan seseorang menjadi wali hakim kecuali ditunjuk secara resmi oleh Menteri Agama.

\section{PENETAPAN KEABSAHAN IMAM KAMPUANG SEBAGAI WALI HAKIM OLEH PENGADILAN AGAMA TALU}

Pengadilan Agama Talu dibentuk berdasarkan Keputusan Menteri Agama RI Nomor : 58 Tahun 1957 tanggal 13 Nopember 1957, juga saat itu ditetapkan namanya Mahkamah Syari'yah / Pengadilan Agama Talu yang memiliki Wilayah Yuridiksi sebanyak 11 kecamatan. Pada saat itu Pengadilan Agama Talu belum melaksanakan tugas sebagaimana mestinya dikarenakan belum ada pegawai. Maka untuk pelaksanakan tugas Pengadilan Agama Talu harus berada di bawah naungan Mahkamah Syari'ah Bukittinggi. Setiap ada persidangan maka Majelis Hakimnya didatangkan dari Mahkamah Syariah Bukittinggi, pada saat itu namanya sidang keliling.

Kemudian pada tanggal 8 Agustus 1961, berdasarkan Surat Penetapan Menteri Agama Nomor 58 Tahun 1957 ditetapkanlah Mahkamah Syari'yah /Pengadilan Agama Talu yang bertugas menerima, mengadili dan menyelesaikan perkara dalam wilayah hukumnya yang berkedudukan di Talu Kecamatan Talamau Kabupaten Pasaman.

Pada awal berdirinya kantor Pengadilan Agama Talu berpindah-pindah dengan mengontrak rumah penduduk. Tahun 1978 dengan dana Repelita Pembangunan, maka dibangunlah Balai Sidang di atas tanah Negara seluas 722 M2 dengan luas bangunan 150 M2 yang beralamat di Jalan Wirataman No. 5 Talu Kecamatan Talamau. Pada Tahun 1997 diperluas dengan biaya swadana seluas 48 M2 dan pada tahun 1998 diperluas lagi dengan dana bantuan pemerintah pusat sebuah bangunan baru seluas $150 \mathrm{M} 2$. 
Dengan pemekaran Kabupaten Pasaman menjadi 2 (dua) Kabupaten yaitu Kabupaten Pasaman dan Kabupaten Pasaman Barat melalui Undang-Undang Nomor 3 Tahun 2003 maka Pimpinan Pengadilan Agama Talu saat itu Drs. Marwan AM. yang dilanjutkan oleh Drs. Jasrizal MS. berusaha menghubungi Kepala Daerah Pasaman Barat untuk mendapatkan tanah perkantoran baru di pusat pemerintahan yaitu di Simpang Empat. Maka pada tahun 2005 Pengadilan Agama Talu mendapat izin dari Pj. Bupati Pasaman Barat untuk mendirikan bangunan gedung kantor di atas tanah Negara seluas 2.304 M2 di Simpang Empat.

Pada tahun 2005 dan 2006 dibangunlah Kantor Pengadilan Agama Talu di Simpang Empat sebanyak 2 lantai dengan dua tahapan yaitu dengan DIPA tahun 2005 dan 2006 sehingga total dana sebanyak Rp.1.470.911.000,- (satu miliar empat ratus tujuh puluh juta sembilan ratus sebelas rupiah) dengan luas bangunan 780 M2. Pembangunan gedung tersebut selesai tahun 2006 dan diresmikan oleh Ketua Mahkamah Agung Republik Indonesia Bapak Prof. DR. H. Bagir Manan, SH. MCL pada tanggal 10 Oktober 2006. Pada tanggal 15 Januari 2007 secara resmi Pengadilan Agama Talu pindah dari Talu ke Simpang Empat (Ibu Kota Kabupaten Pasaman Barat) dengan alamat Jl.Jati II Jorong Pasaman Baru, Kecamatan Pasaman Kabupaten Pasaman Barat. Jarak antara gedung kantor lama dengan gedung kantor baru sekitar $30 \mathrm{Km}$.

Sejak tahun berdiri Pengadilan Agama Talu sampai sekarang, Ketua Pengadilan Agama Talu telah dijabat oleh 10 (sepuluh) orang sebagai berikut; yaitu : Muchtar Zaini (1957-1980), Drs. Asmuni (1980-1989), Drs. Sunarto (1989-1992), Drs. H. Thamrin Habib, SH, M.HI (1992-2001), Drs. H. Marwan AM, M.HI (2001-2004), Drs. Jasrizal, MS, M.HI (2004-2008), Drs. Jamalus, M.HI (2008-2011), Drs. Syafri (2011-2014), Dra. Ma'rifah (2014-
2017), dan Drs. Palatua, SH, M.HI (2017sekarang). ${ }^{27}$

Sehubungan dengan pelaksanaan isbat nikah yang dilakukan oleh Pengadilan Agama Talu merupakan pengesahan atas pernikahan yang terjadi antara seorang pria dan wanita di Jambu Baru, Jorong Padang Tujuh Kenagarian Aua Kuniang Kecamatan Pasaman Kab. Pasaman Barat pada tanggal 25 Juli 2011. Pengucapan ijab itu dilafalkan oleh seorang laki-laki yang bukan wali nasab namun beliau adalah seorang imam kampung pada suatu kaum yang bertugas membantu ninik mamak/datuk dalam masalah keagamaan yang lebih spesifik dalam masalah imam shalat sebagaimana halnya dengan jabatan pembantu yang lain seperti bilal dan khatib. ${ }^{28}$

Kasus yang menyebabkan imam kampung bertindak sebagai wali nikah yang sekaligus menjadi wali hakim dikarenakan seorang wanita yang akan menikah tersebut tidak memiliki seorangpun wali nasab yang berhak untuk menjadi wali nikah. Sepasang pria dan wanita tersebut mengurus kehendak pernikahannya tidak resmi melalui Kantor

${ }^{27}$ Pengadilan Agama Talu, Op.cit, h. 2-3

${ }^{28}$ Di nagari Aua Kuniang pimpinan tertinggi dalam tatanan adat istiadat masyarakat Nagari Aua Kuniang adalah Majo Indo. Majo Indo ini membawahi 16 (enam belas) para Ninik Mamak/Datuak. Pada setiap ninik mamak dibantu oleh: Urang Tuo Adat, Urang Tuo Sumando, Urang Tuo Malin (Imam, Katik dan Bila) dan Induak. Dari 16 Ninik Mamak yang ada hanya 2 Ninik Mamak yang dibantu 3 orang (Imam, Katik dan Bila) dan selebihnya terdiri dari 1 orang dengan jabatan rangkap tiga. Dengan demikian maka semua urusan masyarakat adat diserahkan sepenuhnya kepada Ninik Mamak untuk mengatur dan memutuskan persoalan. Ninik mamak/Datuak dapat saja membawahi berbagai suku dan golongan. Sehingga siapa saja yang bersifat pendatang ke daerah tersebut, diharuskan untuk masuk kedalam salah satu ninik mamak yang ada di sana. Hal ini lebih dikenal dengan istilah "mangaku mamak". Karena di Nagari ini pada dasarnya mengenal istilah "mamak ditinggaan mamak didapek-i". Artinya bahwa setiap orang yang meninggalkan mamak di kampungnya mesti mencari mamak di negeri orang lain. Tujuannya agar semua peristiwa baik dan buruk yang menimpa pada satu keluarga akan segera mendapatkan pelayanan masyarakat. Hendro, S. Pd, Wali Nagari Aua Kuniang, Wawancara, (Padang Tujuh, 06 April 2015) 
Urusan Agama Kecamatan setempat, maka untuk memudahkan urusan, mereka mendatangi imam kampung itu disebabkan imam tersebut sering membantu masyarakat yang ingin melaksanakan nikah di bawah tangan. Pada akhirnya calon istri menyerahkan urusan perwaliannya kepada imam tersebut.

Pada sebagian kecil masyarakat yang berada di Jambu Baru ada yang meyakini bahwa imam kampung itu sudah bisa dianggap sebagai wali hakim. Walaupun faktanya mayoritas masyarakat yang berada di sana enggan mengakuinya. Kronologis seorang imam kampung disematkan kepadanya wali hakim oleh sekelumit masyarakat adalah diawali dengan terdapatnya beberapa kasus pernikahan yang terjadi di luar pengawasan Pegawai Pencatat Nikah pada Kantor Urusan Agama Kecamatan (nikah sirri). Wali nikah sering menyerahkan urusan ijab dengan berwakil kepada imam kampung untuk melafalkan ijab. Sehingga dengan seringnya ia terlihat mewakili pelafalan ijab, maka muncul anggapan masyarakat awam bahwa imam kampung sudah berada pada posisi sebagai wali hakim. Padahal justeru hanya sebatas penerima wakil dalam pelafalan ijab. ${ }^{29}$

Dalam wawancara penulis dengan Imam kampung tersebut, ia membenarkan atas pelaksanaan beberapa pernikahan sirri yang pernah dilakukannya. Termasuk salah satunya adalah kasus yang dibicarakan ini. Ia beralasan bahwa demi membantu orang yang tidak mempunyai wali maka sebagai imam kampung berpendapat sah saja untuk menjadi wali nikah dengan posisi wali hakim. Karena wanita tersebut telah menyerahkan urusan perwaliannya kepada dirinya. ${ }^{30}$

Setelah Pengadilan

Agama Talu mengesahkan permohonan isbat nikah tersebut dengan Nomor 502/Pdt.G/2011/PA Talu Tentang Isbat Nikah, maka suami isteri mendaftarkan pencatatan perkawinannya ke KUA Kecamatan Pasaman untuk memperoleh Kutipan Akta Nikah (Buku Nikah). Sehingga tercatatlah perkawinannya dengan Nomor Akta Nikah: 613/12/XII/2011. ${ }^{31}$

Kemudian tentang duduk perkara, "Bahwa, Pemohon dengan surat permohonannya tanggal 24 Oktober 2011 yang telah didaftarkan di kepaniteraan Pengadilan Agama Talu dengan register perkara nomor: 502/Pdt.G/2011/PA.Talu. tanggal 24 Oktober 2011 telah mengemukakan hal-hal yang pada pokoknya sebagai berikut: Bahwa Pemohon telah menikah dengan Termohon pada hari Senin tanggal 25 Juli 2011 di Jambu Baru, Jorong Padang Tujuh Nagari Aua Kuniang, Kecamatan Pasaman, Kabupaten Pasaman Barat yang menjadi wali nikah Wali Hakim setempat Imam dan disaksikan oleh Yose Faisal dan Adi dengan maskawin berupa seperangkat alat shalat;".32

Dalam duduk perkara di atas dapat dinyatakan bahwa pernikahan tersebut termasuk kepada peristiwa nikah yang jauh terjadi setelah tahun 1974. Jika melihat kepada dasar awal bahwa perkara isbat nikah hanya diperuntukkan bagi mereka yang melakukan perkawinan yang tidak tercatat tanpa pengawasan Pegawai Pencatat Nikah (PPN) serta dilaksanakan sebelum diberlakukanya Undang-undang No.1 Th.1974 tentang perkawinan jo Peraturan pemerintah Nomor 9 Tahun 1975; (penjelasan pasal 49 ayat (2) jo Pasal 64 UU No.1 Th. 1974).

Kemudian jika dilihat dari tanggal peristiwa nikah dengan tanggal permohonan isbat nikah, bahwa pernikahan ini termasuk pernikahan yang masih baru terlaksana, karena

\footnotetext{
${ }^{31}$ Wafda, S. Ag, Kepala KUA Kecamatan Pasaman, Wawancara, (Tanggal, 01-09-2016)

32Penetapan Putusan Pengadilan Agama Talu Nomor: 502/Pdt.G/2011/PA. Talu Tentang Isbat Nikah, tanggal 05 Desember 2011.
} 
jarak antara tanggal pernikahan yakni 25 Juli 2011 dengan tanggal permohonan isbat nikah yaitu tanggal 24 Oktober 2011 relatif sangat dekat yakni lebih kurang 3 (tiga) bulan. Untuk itu penulis tidak sependapat untuk menerima permohonan isbat nikah ini karena dipandang tidak mencapai nilai-nilai yang akan digapai dari pembolehan isbat nikah, yakni mencegah agar tidak terjadinya mudharat. Hemat penulis bahwa tingkat darurat untuk menerima isbat nikah ini belum ada. Lain halnya jika sudah hitungan bertahun-tahun sehingga berdampak kepada status harta gono-gini dan lainnya. Kemudian tahun 2011 merupakan era yang sudah terorganisir sangat baik, mudah dan transparan di jajaran Kementerian Agama dalam pengurusan pencatatan nikah. Sehingga alasan klasik yang menyatakan sulit dalam mengurus surat nikah adalah tidak logis. Terlebih lokasi pernikahan dan domisili suami istri dengan Kantor Urusan Agama Kecamatan setempat relatif dekat sekitar 3 (tiga) $\mathrm{km}$.

Selanjutnya masih dalam persoalan duduk perkara, "Bahwa pernikahan Pemohon dan Termohon belum dikaruniai anak;". Menurut penulis bahwa dengan dasar duduk perkara di atas menjadi penguat agar tidak menerima permohonan isbat nikah ini. Sebab salah satu nilai yang akan digapai dalam isbat nikah adalah menolak mudarat yang muncul dari akibat pernikahan yang tidak tercatat. Dalam kasus ini anak yang menjadi salah satu penyebab agar terhindar dari mudarat oleh akibat hukum pernikahan liar tidak ada. Mudarat yang dimaksud adalah kesulitan dalam pengakuan anak dan kepemilikan bukti autentik kelahiran berupa akta kelahiran.

Setelah melihat bagian duduk perkara, maka pada bagian tentang hukum dalam putusan pengadilan ini ada beberapa pertimbangan yang akan penulis ungkapkan yang disertai dengan pertimbangan majlis hakim yang menyidangkan perkara ini melalui wawancara. Kemudian penulis akan memberikan pendapat terhadap pertimbanganpertimbangan hukum tersebut.

Dalam pertimbangan hukum disebutkan bahwa: "Menimbang, yang bertindak sebagai wali nikah adalah Wali Hakim setempat Termohon bernama Imam Jazam dan bersaksi dua orang saksi bernamaYose Faisal dan Attawafi dengan mahar seperangkat alat shalat dibayar tunai, diakui oleh Termohon dan dikuatkan dengan keterangan dua orang saksi di persidangan walaupun saksi tidak tahu persis, maka Majelis berpendapat telah terbukti pernikahan Pemohon dan Termohon sesuai ketentuan Pasal 14 sampai Pasal 30 KHI jo Pasal 6 dan 7 Undang-undang Nomor 1 Tahun 1974, oleh karena itu perkawinan Pemohon dan Termohon telah memenuhi rukun dan syarat perkawinan;

Pertimbangan hukum yang digunakan oleh majlis hakim mengenai wali nikah yang bertindak sebagai wali hakim setempat adalah seorang Imam yang bernama Imam Jazam adalah hal urgen yang harus dikritisi. Sebab Imam Jazam adalah seorang Imam kampung yang bukan secara eksplisit tidak terkategori sebagai wali hakim sebagaimana yang dimanatkan dalam KHI Pasal 20 poin 2 huruf b. Kemudian untuk mempertegas maksud wali hakim pada KHI Pasal 20 poin 2 huruf b ini mesti singkron dengan apa yang dimanatkan dalam KHI Pasal 1 huruf b yang berbunyi "Wali hakim ialah wali nikah yang ditunjuk oleh Menteri Agama atau pejabat yang ditunjuk olehnya yang diberi hak dan kewenangan untuk bertindak sebagai wali nikah”. Sedangkan Imam Jazam bukan orang yang ditunjuk oleh Menteri Agama.

Berdasarkan penjelasan di atas maka penulis menilai bahwa Majlis hakim belum melihat pasal-pasal dalam KHI tentang wali nikah secara universal dan utuh sebagaimana yang sudah tertuang dalam KHI. Dengan demikian maka penetapan seorang Imam kampung sebagai wali hakim dalam kasus ini 
semestinya tidak diterima, sebab syarat wali hakim belum terpenuhi.

Kemudian pertimbangan hukum berikutnya, "Menimbang, bahwa Pemohon mengajukan isbat nikah ke Pengadilan Agama Talu, karena belum mamiliki buku nikah, sekarang pemohon membutuhkan bukti pernikahan, diakui oleh Termohon dan didukung dengan keterangan dua orang saksi di persidangan, maka Majelis berkesimpulan perkawinan Pemohon dan Termohon dilaksanakan setelah lahir Undang-undang Nomor 1 tahun 1974, akan tetapi karena tidak ada halangan, perkawinan Pemohon dan Termohon telah cukup rukun dan syarat perkawinan dan tidak mempunyai buku nikah, sedangkan untuk memperoleh buku nikah yang sangat diperlukan hanya dengan isbat satu-satunya jalan, oleh karena itu permohonan Pemohon dapat dipertimbangkan;"

Pertimbangan hukum dengan belum memiliki buku nikah dan hanya isbat nikah sebagai satu-satunya jalan untuk memperoleh pencatatan adalah merupakan pertimbangan yang perlu untuk dikritisi. Sebab jika Pemohon dan Termohon punya kemauan yang baik untuk mendaftarkan pernikahannya ke KUA Kecamatan setempat maka akan jauh lebih efektif dan efesien dibanding melakukan isbat ke Pengadilan Agama kemudian mendaftarkan lagi ke KUA Kec. Setempat. Karena prosedur pengurusan pendaftaran dan pencatatan nikah ke KUA Kecamatan setempat relatif lebih efektif, mudah dan efesien baik itu dari aspek persyaratan maupun prosesi pelaksanaan. Bahkan jika Pemohon dan Termohon punya keinginan mempercepat pernikahan dengan kurang dari 10 (sepuluh) hari kerja terhitung dari pendaftaran nikah seperti 3 (tiga) atau 4 (empat) hari sesudah mendaftar maka KUA Kecamatan setempat dapat mengabulkan jika yang bersangkutan memperoleh surat dispensasi nikah dari Camat setempat. Untuk pengurusan di kantor Camat waktu yang digunakan relatif mudah hanya dengan durasi waktu hitungan menit. Dan dalam penyerahan buku nikah akan segera diserahkan sesaat setelah proses ijab qabul. Sedangkan pengurusan isbat nikah di pengadilan membutuhkan waktu yang lama sekitar lebih kurang 3 (tiga) bulan mulai dari sejak tanggal pendaftaran yaitu tanggal 24 Oktober 2011 dan selesai pada tanggal 05 Desember 2011

Dengan demikian tentu hal ini menumbuhkan pertanyaan kembali apa benar Pemohon dan Termohon sudah berupaya ke KUA Kecamatan atau mungkin saja ada persyaratan prinsipil yang tidak dapat dipenuhi oleh Pemohon dan Termohon untuk mendaftarkan pencatatan nikah mereka ke KUA Kecamatan setempat.

Berdasarkan wawancara penulis dengan majlis hakim yang memeriksa perkara ini yaitu Bapak Drs. H. Palatua, SH. MHI Ketua Majelis, Baginda, S.Ag dan Sudilihartati, SHI sebagai hakim-hakim anggota, sepakat memberikan memberikan beberapa pertimbangan hukum untuk menerima dan mengabulkan permohonan pemohon sebagai berikut: ${ }^{33}$

Pertama, bahwa dari aspek administrasi pendaftaran pencatatan pernikahan di KUA Kecamatan pada waktu itu dipandang belum tertib admnistrasi. Kedua, bahwa anggapan masyarakat yang tumbuh di sekitar tempat tinggal Imam Jazam sebagai wali hakim memiliki tingkat kepercayaan yang baik sehingga dipandang terpercaya untuk menyerahkan urusan agama termasuk persoalan menjadi wali hakim. Dalam hal ini diistilahkan dengan Living Law yang hidup pada masyarakat sekitar. Ketiga, Majlis hakim tetap membenarkan bahwa prinsip wali hakim adalah pemerintah. Namun untuk kasus tertentu selain yang ditunjuk pemerintah seperti Imam kampung yang dipercaya sudah

${ }^{33}$ Drs. H. Palatua, SH. MHI Ketua Majelis, Baginda, S.Ag dan Sudilihartati, SHI sebagai Majlis Hakim, W awancara, (Simpang Empat, 06 April 2018) 
dapat dikatakan sebagai wali hakim. Akan tetapi khusus untuk kasus ini tidak akan diterapkan pada kasus dan perkara pernikahan yang lain. Sehingga belum tentu akan sama putusan dan pertimbangannya.

Menyikapi dari beberapa pertimbangan hukum yang penulis peroleh dari majlis hakim di atas, ada beberapa analisa yang sangat penting untuk menjadi perhatian sehingga tidak terburu-buru menilai dengan pertimbangan yang ada.

Petimbangan hukum yang menilai belum tertibnya administrasi dalam pencatatan nikah adalah penilaian yang tidak berdasar. Sebab KUA Kecamatan Pasaman sebagai KUA Kecamatan setempat merupakan kantor yang telah lama berdiri sejak tahun 1960. Kemudian telah mencapai prestasi yang baik sebagai KUA Kecamatan percontohan terbaik di Kab. Pasaman Barat dan menjadi utusan Kab. Pasaman Barat sebagai KUA Kecamatan terbaik di tingkat Provinsi Sumatera Barat. ${ }^{34}$ Sebagai KUA Kecamatan terbaik di Kab. Pasmaan Barat tentu tidak dapat diterima logika bahwa admnistrasi pernikahan dinilai belum tertib.

Apabila melihat dari aspek peraturan, bahwa berbagai aturan perkawinan mulai dari UU No. 1 tahun 1974 tentang Perkawinan, PP No.9 tahun 1975 tentang Pelaksanaan UU No. 1 tahun 1974 tentang Perkawinan, Instruksi Presiden RI Nomor 1 Tahun1991 tentang Kompilasi Hukum Islam, Peraturan Menteri Agama No 30 Tahun 2005 tentang Wali Hakim, Peraturan Menteri Agama No. 11 Tahun 2007 tentang Pencatatan Perkwainan serta beberapa aturan turunan yang mengatur tentang Perkawinan dan administrasi sudah sangat jelas, lengkap dan mudah. Bahkan program gratis biaya nikah bagi yang tidak mampu juga termasuk program yang

${ }^{34}$ Wafda, S. Ag, Kepala KUA Kecamatan Pasaman, Wawancara, (Tanggal, 01-09-2016) diunggulkan dalam jajaran Kementerian Agama.

Dari aspek petugas dan pelaksana pelayanan admnistrasi serta pengawas pernikahan juga sudah mumpuni. Sebab di samping adanya Kepala KUA Kecamatan, Peghulu juga hadir dalam pengawasan bahkan setiap jorong telah ditetapkan Pembantu Pegawai Pencatat Nikah (P3N) sebagai perpanjang tangan Kepala KUA Kecamatan dalam rangka memudahkan urusan khusunya bidang perkawinan. Dengan demikian maka alasan administrasi belum tertib tidak dapat diterima.

Untuk pertimbangan hukum bahwa Living Law yang berkembang pada sekitar masyarakat bahwa Imam Jazam sudah dianggap mewakili masyarakat dalam urusan agama bahkan sebagai wali hakim adalah penilaian yang belum mewakili semua pendapat masyarakat umum di sana. Sebab seandainya sudah sepakat Imam itu sebagai orang yang telah mewakili tentu mayoritas masyarakat akan mengurus pernikahan kepada Imam tersebut. Akan tetapi faktanya masyarakat yang berada di lingkungan Imam tersebut tidak sepakat dan enggan untuk mengurus kepada Imam tersebut..$^{35}$ Kemudian untuk pernikahan yang dilaksanakan Imam kampung itu semuanya adalah nikah sirri yang tidak diketahui oleh banyak orang. Mungkin saja orang tidak mau mempermasalahkan pernikahan itu karena tidak peduli atau merasa tidak ada kepentingan bagi mereka. Maka diamnya masyarakat belum tentu dikatakan sepakat. Dengan demikian maka anggapan sebagian kecil masyarakat yang tumbuh dalam persoalan wali hakim ini tidak dapat diterima dan berlaku bagi semua masyarakat.

Kemudian pertimbangan hukum oleh majlis hakim tentang prinsip wali hakim adalah pemerintah terkecuali untuk kasus-kasus

${ }^{35}$ Hanafi, S. Pd. I, Mantan P3N Jorong Padang Tujuh, Lubuk Landur, dan Bukik Nilam, Wawancara, (Padang Tujuh, 12 April 2017). 
tertentu seperti pernikahan ini maka itu merupakan pertimbangan yang tidak konsisten. Inkonsistensi ini berdampak bias terhadap makna dan hakikat wali hakim itu sendiri yang ujungnya akan mempengaruhi wibawa hukum. Dan sebagai produk hukum dari Pengadilan Agama maka semestinya hal ini tidak ditemukan.

Putusan Pengadilan Agama dengan Nomor: 502/Pdt.G/2011/PA. Talu Tentang Isbat Nikah tentang Isbat Nikah ini merupakan produk hukum yang memiliki akibat hukum yang sangat besar ke depannya. Sahnya suatu pernikahan secara substansi telah menilai benar terhadap semua unsur rukun dan syarat sah pernikahan. Hal ini secara sosiologis juga akan memberikan dampak yang sangat urgensi mengenai substansi pemahaman terhadap wali hakim serta wibawa berbagai aturan hukum yang diproduk oleh pemerintah yang mengatur tentang perkawinan.

Dari aspek wali hakim bahwa dasar hukum pensyaria'tan wali hakim adalah hadis Rasulullah Saw yang berasal dari 'Aisyah, Nabi Muhammad Saw bersabda bahwa wanita manapun yang menikah tanpa izin walinya maka nikahnya batil, dan wanita itu tetap memperoleh maharnya disebabkan apa yang telah menimpa kepadanya, jika mereka enggan maka sultan (penguasa) menjadi wali nikah bagi yang tidak memiliki wali.

Wali hakim adalah penguasa resmi yang dapat bertindak sebagai wali nikah (wali hakim) ketika wanita yang hendak menikah tidak memiliki wali nasab, atau ada sebab lain yang mengaharuskan berpindah dari wali nasab kepada wali hakim. Agar pelaksanaan pernikahan itu tidak memiliki kendala maka penguasa dapat menunjuk pejabat kepada orang-orang yang dianggapnya mampu dan cakap dalam menjalankan tugasnya. Keberadaan hadis Rasulullah SAW yang menyebutkan Sultan sebagai wali hakim, merupakan isyarat tentang betapa penting dan harusnya penguasa memiliki kewenangan penuh dan hadir dalam meyeleseaikan kasus perkawinan. Dan untuk mempermudah tidak terkendalanya pelaksanaan pernikahan itu maka penguasa dapat menunjuk pejabat kepada orang-orang yang dianggapnya mampu dan cakap dalam menjalankan tugasnya sebagai wali hakim.

Adapun mengenai pertimbangan majlis hakim yang berpendapat bahwa seorang yang sudah dipercaya dapat menjadi wali hakim dengan permintaan dari seorang wanita yang akan menikah tentunya perlu dikaji lebih mendalam. Karena dalam sebuah khabar yang bersumber dari Ikrimah bin Khalid, bahwa Umar pernah membatalkan pernikahan seorang perempuan yang menyerahkan urusan perwaliannya kepada seorang laki-laki yang tidak mempunyai hubungan nasab dengannya, bahkan Umar menghukum keduanya dengan mencambuk mereka dan kemudian mengulang pernikahan tersebut.. ${ }^{36}$

Kemudian untuk pemahaman tentang meyerahkan urusan perwalian kepada seorang yang dipercaya, ulama telah memberikan persyaratan yang jelas. Sayyid Sabiq mengutip pendapat Al-Qurthubi menetapkan bahwa pemberlakuan terhadap penyerahan kepada orang yang dipercaya karena di daerah wanita itu tidak ada wali nasab dan penguasa. ${ }^{37}$ Begitupun Al-Sayyid al-Bakriy ibn al-Sayyid Muhammad Syatha al-Dimyathi al-Mishri juga menegaskan bahwa jika semua wali nasab dan penguasa sudah punah maka dapat diserahkan kepada pria yang dapat dpercaya. ${ }^{38}$

Menyikapi pendapat ulama di atas penulis berpendapat bahwa fatwa pembolehan itu salah satu pertimbangannya adalah untuk menghindari mafsadat yang muncul jika tidak dilaksanakan pernikahan. Sedangkan

${ }^{36}$ Muhammad ibn Idris al-Syafi'i, al-Umm, ([t.tp]: Dar al-Wafa', 2001), Juz VI, h. 34

${ }^{37}$ Sayyid Sabiq, Fiqhal-Sunnah, (Beirut: Dar al-Fikr, 2008), Jilid II, h.523

${ }^{38}$ Sayyid al-Bakriy ibn al-Sayyid Muhammad Syatha al-Dimyathi al-Mishriy, I'anah..., h. 318. Lihat juga Ibn Rusyd al-Hafidi, Bidayah..., h. 39 
pernikahan yang terjadi di tahun 2011 ini tidak memenuhi unsur kesulitan dalam mencari pemerintah dalam menangani persoalan wali nikah.

Kemudian dari aspek sosiologis, bahwa dengan ditetapkannya perikahan yang dilaksanakan oleh Imam kampung sebagai wali hakim maka hal ini berdampak kepada pemahaman praktis yang keliru bahwa Sultan/penguasa dapat ditandingi oleh penunjukan segelintir orang untuk mengangkat wali hakim, sehingga maksud dan nilai luhur yang terkandung dalam hadis mengenai Sultan sebagai wali hakim menjadi lemah.

Selanjutnya pengesahan perkawinan oleh Pengadilan Agama terhadap pernikahan ini akan berdampak kepada menjamurnya pernikahan liar dengan menyerahkan urusan perwalian kepada Imam kampung sebagai wali hakim. Jika hal ini dibiarkan terjadi maka akan membentuk preseden buruk sehingga orang akan cenderung menganggap enteng dan mengabaikan pencatatan nikahnya secara langsung pada saat perkawinan.

Melihat mafsadat yang muncul sebagai akibat dari putusan Pengadilan Agama di atas maka tentu hal ini penting untuk dihindari. Hal ini sesuai dengan kepada kaidah fikih:

$$
\text { درء المفاسد أولى على جلب المصالح }
$$

"Menolak kerusakan atau mabdarat lebih utama dari pada mendapatkan kemashlahatan". 39

Pada satu sisi bahwa ketika tidak menerima perkara pernikahan ini serta tidak mengesahkanya sepintas akan menimbulkan mafsadat bagi pemohon dan termohon, yakni tidak diakuinya pernikahan mereka dalam hukum positif. Namun dari sisi lain bahwa dengan memeriksa dan disahkan perkara ini juga menimbulkan beberapa mafsadat yang banyak dan besar. Dengan demikian maka meghindari mafsadat yang lebih besar lebih

${ }^{39}$ Shalih ibn Ghanim al-Sadlan, al-Qawa'id alFiqhiyyah al-Kubra, (Riyadh: Dar Balnasiyah, 1417 H), Cet I, h. 507 utama dibandingkan menghindari mafsadat yang lebih ringan. Artinya bahwa mafsadat yang muncul dengan tidak memeriksa dan meneima perkara tersebut hanya sebatas belum diakui perkawinannya. Bahkan jika ingin mendaftarkan dan mencatatkan ke KUA Kecamatan setempat akan lebih mudah dibandingkan dengan menjalani proses isbat nikah. Sedangkan mafsadat yang muncul dari pengesahan pernikahan ini adalah melemahkan terhadap substansi hadis Rasulullah Saw mengenai wali hakim, luntur dan melemahnya wibawa pemerintah dalam menetapkan wali hakim bahkan akan menjadi dasar bagi masyarakat untuk menikah liar dengan meggunakan jasa Imam kampung sebagai wali hakim. Dalam hal ini dapat ditimbang kembali dengan menggunakan kaidah fikih:

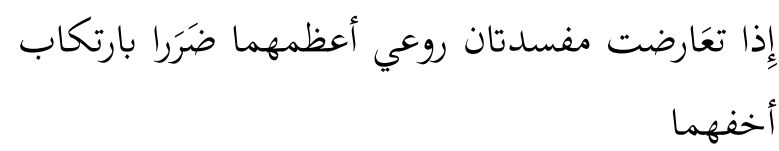

"Apabila terdapat pertentangan antara dua mafsadat, maka mesti dijaga agar tidak terjadi mafsadat yang lebih besar dari antara keduanya dengan melaksanakan sesuatu walaupun mengandung mafsadat yang lebih kecil". ${ }^{40}$

Dilihat dari hukum positif di Indonesia, pertimbangan majleis hakim yang menyatakan bahwa pernikahan dengan Imam setempat sebagai wali hakim dipandang telah memenuhi rukun dan syarat sebagaimana tertuang dalam KHI Pasal 20 poin 2 huruf $b$ adalah suatu pertimbangan yang belum komprehensif dalam menggunakan KHI sebagai dasar pertimbangan. Sebab dalam KHI Pasal 1 huruf b ternyata telah dipertegas bahwa yang dimaksud dengan wali hakim ialah wali nikah yang ditunjuk oleh Menteri Agama atau pejabat yang ditunjuk olehnya yang diberi hak dan kewenangan untuk bertindak sebagai wali nikah.

Aspek normatif atau kepastian hukum juga menjadi buram, karena 
penetapan dan putusan tersebut tidak sesuai dengan apa yang diamanahkan oleh UU. No.1 tahun 1974 dan Kompilasi Hukum Islam yang mana keduanya telah mengatur dengan jelas tata cara pernikahan dan isbat nikah, serta persoalan wali hakim yang diatur dalam KHI dan turunan peraturan lainnya yang telah diakomodir oleh Menteri Agama.

Secara filosofis seluruh aturan tentang pencatatan perkawinan untuk menciptakan kondisi yang kondusif dan teratur untuk masyarakat dalam bidang perkawinan. Sehingga perkawinan yang serampangan akan dapat dikontrol dan dikelola dengan baik. Namun jika melihat perkara yang penulis angkatkan ini dapat dipastikan munculnya anggapan masyarakat muslim bahwa pemerintah belum dipandang baik untuk menetukan dan mengatur dalam bidang perkawinan. Dampak ini menurut penulis sangat berbahaya. Dan pada akhirnya tidak tertutup kemungkinan masayarakat tidak lagi memperdulikan kehidupan bangsa dan kenegaraan dalam bidang hukum, yang pada akhirnya sampai pada anggapan bahwa pelaksanaan ajaran Islam tidak membutuhkan keterlibatan negara. Untuk itu konsep saddaldzariah (menutup jalan untuk terjadinya kemudaratan) harus dihadirkan agar mudarat yang lebih besar tidak terjadi.

\section{KESIMPULAN}

Pengangkatan imam kampung sebagai wali hakim dalam sebuah perkawinan tidak didasarkan kepada alasan yang dapat dibenarkan oleh syarak, karena secara subsatansi wali hakim dalam konstelasi hukum
Islam dan hukum positif yang berlaku di Indonesia adalah pemerintah atau orang yang ditauliyahkan pemerintah untuk menjadi wali hakim. Dalam permohonan isbat nikah yang telah dikabulakan oleh majlis hakim Pengadilan Agama Talu Nomor: 502/Pdt.G/2011/PA telah mengabaikan aspek penting dalam sebuah produk hukum karena kurang memperhatikan aspek hukum Islam (fiqh) yang tidak pernah memberi peluang kepada orang yang tidak mempunyai hubungan nasab dengan seorang perempuan. Kemudian dari aspek yuridis, putusan tersebut terkesan tidak konprehensif dalam menggunakan Undang-Undang Perkawinan dan KHI sebagai rujukan dalam isbat nikah. Tentu akan berujung penilaian cacat dan ketidakpastian hukum. Dari aspek filosofis, akan memunculkan nilai negatif kepada tatanan hukum. Sakralitas norma dan lembaga negara yang awalnya memiliki tujuan mulia akan terganggu dengan sikap remeh kepada norma, lembaga dan petugas negara dalam menangani pernikahan. Untuk itu konsep saddaldrariah harus dihadirkan agar tidak terjadi kerusakan yang lebih parah seperti tidak perduli kepada negara dan tidak melibatkan negara dalam perkawinan. Sedangkan dari aspek sosiologis, putusan tersebut tidak memberi manfaat yang banyak dalam tatanan sosial, bahkan akan memicu terjadi pernikahan liar yang merugikan berbagai pihak. 


\section{DAFTAR KEPUSTAKAAN}

Sayyid Sabiq, Fiqh al-Sunnah, Beirut: Dar al-Fikr, 2008, Juz II.

Direktorat Jenderal Bimbingan Masyarakat Islam dan Penyelenggaraan Haji Departemen Agama RI, Himpunan Fatwa MajelisUlama Indonesia, (Jakarta: [t.tp], 2003), h. 163

M. Yunus, Hukum Perkawinan dalam Islam menurut Empat Mą̧hab, Jakarta: PT. Hidakarya Agung, 1996), h. 55.

Muhammad ibn Ismail, Subul al-Salam, (Semarang: Toha Putra), Juz III.

Penetapan Putusan Pengadilan Talu Nomor: 502/Pdt.G/2011/PA. Talu tentang Isbat Nikah.

Direktorat Jenderal Pembinaan Kelembagaan Agama Islam, Kompilasi Hukum Islam, ([t.tp]:[t.p], 2000), h. 15

Sayyid Sabiq, Fiqhal-Sunnah, JilidII, (Beirut:Daral-Fikr,2008), h.511. Lihat juga Wahbah al-Zuhayli, Fiqh al-Islam wa Adillatuh, (Damaskus: Dar al-Fikr, 1989), Cet ke-2, Juz VII, h. 746

Mahmud Yunus, Kamus Arab-Indonesia, Jakarta: Yayasan Penyelenggara Penterjemah dan Pentafsir Alquran,1973), h.5-6.

Badran Abu al- 'Ainain Badran, al-Figh al-Muqaran li al-Ahwal al-Syakhsiyyah, (Beirut Lubnan: Dar al- Nahdah al 'Arabiyyah, [t.th]), Juz I, h. 15-16

Muhammad Jawad Mughniyah, Fiqh Lima Madæhab: Ja'fari, Hanafi, Maliki, Syafi'i, Hambali, Terj., (Jakarta: Penerbit Lentera, 2006), h. 176

Amir Syarifuddin, Hukum Perkawinan di Indonesia, (Jakarta: Kencana, 2006), h.96

Abu al-Fida' Ismail ibn Umar ibn Katisr al-Qarasyi al-Bashari, Tafsir al-Qur'an al-'Azbim, ([t.tp]: Dar al-Thayyibah, 1999), Juz. I, h. 631

Muhammad Ali al-Sayis, Tafsir Ayat al-Ahkam, ([t.tp]: [t.terbit], 2002), Juz ke-I, h. 161

Ibn Rusyd al-Hafidi, Bidayah al-Mujtahid wa Nihayah al-Muqtashid, (Kairo: Dar al-Hadits, 2004), Juz III, h. 37.

Abu Dawud Sulaiman ibn al-Asy'ats al-Sijistani, Sunan Abi Dawnd, (Surabaya:Maktabah Dahlan, [t.th]), Jilid 2, h229

Imam Muhammad ibn Idris al-Syafi'i, al-Umm, ([t.tp]: Dar al-Wafa', 2001), Juz VI, h. 34

Ahmad Husairi, al-Nikah wa al-Qadhaya al-Muta'aliqah Bibi, (Kairo: Maktabah Kulliatil Azhar, 1968), h. 508

Sayyid al-Bakri ibn al-Sayyid Muhammad Syatha al-Dimyathi al-Mishri, I'anath al-Thalibin, ([ttp]: al-Haramain, [t.th]), Juz III, h. 318 
Hanafi, S. Pd, Mantan Pegawai Pembantu Pencatat Nikah (P3N) di Nagari Aua Kuniang, Wawancara, (Padang Tujuh, 13 November 2015)

Imam Jazam bin Yunus, Imam Kampung, , Wawancara, (Tanggal, 01-09-2016)

Wafda, S. Ag, Kepala KUA Kecamatan Pasaman, Wawancara, (Tanggal, 01-09-2016)

Penetapan Putusan Pengadilan Agama Talu Nomor: 502/Pdt.G/2011/PA. Talu Tentang Isbat Nikah, tanggal 05 Desember 2011.

Drs. H. Palatua, SH. MHI Ketua Majelis, Baginda, S.Ag dan Sudilihartati, SHI sebagai Majlis Hakim, Wawancara, (Simpang Empat, 06 April 2018)

Wafda, S. Ag, Kepala KUA Kecamatan Pasaman, Wawancara, (Tanggal, 01-09-2016)

Hanafi, S. Pd. I, Mantan P3N Jorong Padang Tujuh, Lubuk Landur, dan Bukik Nilam, Wawancara, (Padang Tujuh, 12 April 2017).

Abu Dawud Sulaiman ibn al -Asy'ats al-Sijistani, Sunan Abi Dawud, (Surabaya: Maktabah Dahlan, [t.th]), Jilid II, h. 229

Muhammad ibn Idris al-Syafi'i, al-Umm, ([t.tp]: Dar al-Wafa', 2001), Juz VI, h. 34

Shalih ibn Ghanim al-Sadlan, al-Qawa'id al-Fiqhiyyah al-Kubra, (Riyadh: Dar Balnasiyah, 1417 H), Cet I, h. 507 